\title{
Questions for the Critics of Judicial Review
}

\author{
Saikrishna B. Prakash* \\ John C. Yoo**
}

\section{Introduction}

Judicial review remains one of the American Constitution's most controversial features. It has made American judges some of the most powerful in the world, with a potent role in shaping the everyday lives of Americans. Perhaps for this reason, scholars and judges continue to question its origins and legitimacy, with recent articles appearing in the Harvard Law Review and the Columbia Law Review, ${ }^{1}$ and with Justices Stephen Breyer and David Souter challenging the constitutionality of judicial review in federalism cases. $^{2}$

In earlier articles, we laid out the origins of judicial review. ${ }^{3}$ Rather than reiterating the affirmative case for judicial review, here we respond directly to the arguments of the leading recent critic, Professor Larry Kramer. ${ }^{4}$ We have no quarrel with Professor Kramer's uncontroversial (and indeed, so far as we know, uncontroverted) statement that the Founders envisioned that the Constitution would be enforced through popular means such as voting, petitioning, and mobbing. ${ }^{5}$ We likewise agree with his assertion that the Constitution was never meant to enshrine a Cooper $v$. Aaron ${ }^{6}$ type of judicial supremacy. ${ }^{7}$ Yet, we profoundly disagree with Professor Kramer's controversial claims that the Constitution, as originally understood, never authorized

* Professor of Law, University of San Diego School of Law.

** Professor of Law, University of California at Berkeley School of Law (Boalt Hall); Visiting Professor of Law, University of Chicago; Visiting Fellow, American Enterprise Institute. We thank Brad Clark, John Manning, and Maeva Marcus for helpful comments. We also thank Mike Rappaport and Larry Solum for useful discussions.

1 See Larry D. Kramer, The Supreme Court Term 2000-Foreword: We the Court, 115 Harv. L. Rev. 4 (2001) [hereinafter Kramer, We the Court]; Larry D. Kramer, Putting the Politics Back into the Political Safeguards of Federalism, 100 Colum. L. Rev. 215 (2000); see also Larry D. Kramer, When Lawyers Do History, 72 Geo. WAsh. L. REv. 387 (2003) [hereinafter Kramer, When Lawyers Do History].

2 See, e.g., United States v. Morrison, 529 U.S. 598, 660 (2000) (Breyer, J., dissenting); id. at 647 (Souter, J., dissenting).

3 Saikrishna B. Prakash \& John C. Yoo, The Origins of Judicial Review, 70 U. CHI. L. REv. 887 (2003) [hereinafter, Prakash \& Yoo, The Origins of Judicial Review]; Saikrishna B. Prakash \& John C. Yoo, The Puzzling Persistence of Process-Based Federalism Theories, 79 Tex. L. Rev. 1459 (2001); John C. Yoo, The Judicial Safeguards of Federalism, 70 S. CAL. L. REv. 1311 (1997) [hereinafter Yoo, The Judicial Safeguards of Federalism].

4 See Kramer, We the Court, supra note 1.

5 See id. at 60.

6 Cooper v. Aaron, 358 U.S. 1 (1958).

7 See Kramer, We the Court, supra note 1, at 5. 
judicial review, ${ }^{8}$ and that the Founders regarded popular constitutional methods as the exclusive means of safeguarding the Constitution. ${ }^{9}$

First, Professor Kramer, like Professors Jesse Choper ${ }^{10}$ and Herbert Wechsler ${ }^{11}$ before him, ignores the constitutional text and structure. Fairly read, the Constitution's text and structure establishes judicial review in a number of ways. ${ }^{12}$ Second, the Constitution's text, as well as constitutional practice at the time of the Founding, contradicts Professor Kramer's theory that the Founders meant the Constitution to be a political-legal document-a document to be enforced exclusively through popular means. Indeed, Professor Kramer's admission that the Constitution is judicially enforceable against the states undermines his own theory. Third, we believe that Professor Kramer has made methodological errors in his use of the historical materials. In particular, he never squares his claims with the secondary historical literature that runs counter to his thesis. Moreover, he implicitly adopts the stance that, in order for something to be historically established, there must be a solely quantitative level of historical proof; in his argument, the quality of the evidence is apparently of no moment. Fourth, the historical evidence, both quantitatively and qualitatively, refutes Professor Kramer's conclusions. The Founders acknowledged that the Constitution authorized judicial review dozens of times, and no Founder appears ever to have argued, during the ratification fight, that the Constitution either barred or did not permit judicial review. Ironically, though Professor Kramer belittles the evidence in favor of the constitutionality of judicial review, there is virtually no evidence supporting his opinion that the Constitution's political safeguards left no room for judicial review.

\section{Text and Structure}

Perhaps the most serious flaw with Professor Kramer's argument is its surprising failure to consider constitutional text and structure. After all, Professor Kramer makes both historical and legal claims. To make the latter type of claim, one must at least attempt to make sense of constitutional text and structure.

In our earlier work, we argued that judicial review arises from provisions such as the Supremacy Clause and Article III's vesting of the judicial power

8 See id. at 64 .

9 See id. at 26.

10 See generally Jesse H. Choper, Judicial Review and the National Polmical Pro cess: A Functional Reconsideration of the Role of the Supreme Court (1980).

11 See generally Herbert Wechsler, The Political Safeguards of Federalism: The Role of the States in the Composition and Selection of the National Government, 54 Colum. L. REV. 543 (1954).

12 Professor Kramer's comment claims that we have committed the mistake of confusing legal and historical inquiries by asking what the Framers should have thought the constitutional text and structure implied for judicial review. Kramer, When Lawyers Do History, supra note 1, at 411-12. If that is his impression, we wish to correct it here. We offer these textual and structural arguments not merely as claims as to what the Framers subjectively may have thought the Constitution meant. We also advance the textual and structural arguments as the best public understanding of that text and as a free-standing interpretation of the Constitution that speaks to nonoriginalists and originalists alike. 
in the federal courts in all cases arising under the Constitution and federal laws. ${ }^{13}$ We also explained that, because of its status as a coordinate branch of government, the judiciary must refuse to enforce unconstitutional laws in the course of performing its unique function of deciding cases or controversies. ${ }^{14}$ Rather than merely recapitulating our claims, we focus on the textual and structural difficulties arising from Professor Kramer's claim that the Constitution does not authorize judicial review.

\section{A. Text}

Professor Kramer's argument fails to consider the meaning of several important constitutional provisions. First, Article III, section 2, states that the "judicial Power shall extend to all Cases, in Law and Equity, arising under this Constitution."15 This phrase gives federal courts jurisdiction to hear cases that challenge the constitutionality of governmental actions. Cases involving federal statutes that conflict with the Constitution fall within this grant. In deciding such cases, federal courts have to choose between the Constitution and a federal law, and presumably would choose the written Constitution-especially because nothing in the Constitution instructs a federal court to treat federal statutes on par with the Constitution. Nonetheless, Professor Kramer fails to interpret this provision at all.

One supposes that several arguments could be open to Professor Kramer. He could argue, as did Professor Bickel, that Article III, section 2, grants jurisdiction but does not order a court to enforce the Constitution over a conflicting federal statute. ${ }^{16}$ Or, he could argue, as did Professor Choper, that Article III, section 2, only extends federal jurisdiction to cases in which state law conflicts with the Constitution, and that in such cases the courts could invalidate the state law. ${ }^{17}$ These efforts, however, read into the Constitution exceptions that do not appear in the text. There is no textual exception to the "arising under" jurisdiction that would allow suits challenging the constitutionality of state law, but not federal law. Nor are federal courts ever directed either automatically to uphold the constitutionality of federal law, or to ignore arguments on the constitutionality of a federal law. Professors Bickel and Choper, who concede that, in cases involving state law, the Arising Under Clause gives federal courts the authority to interpret and enforce the Constitution, effectively read into Article III, section 2, a choice-of-law clause that requires the federal judiciary to choose federal statutes above the Constitution itself when the two are in conflict. In enacting the Judiciary Act of 1789,18 the first Congress certainly did not read the language in this manner when it confirmed that the Supreme Court enjoyed the authority to affirm or reverse state court decisions that had found a federal statute to be

\footnotetext{
13 Prakash \& Yoo, The Origins of Judicial Review, supra note 3, at 921-22.

14 Id. at 916.

15 U.S. CONST. art. III, $\S 2$.

16 See Alexander M. Bickel, The Least Dangerous Branch: The Supreme Court AT THE BAR Of Politics 13-14 (1962).

17 See Prakash \& Yoo, The Origins of Judicial Review, supra note 3, at 900.

18 Judiciary Act of 1789 , ch. 20, 1 Stat. 73.
} 
unconstitutional. ${ }^{19}$ After all, if the Supreme Court was to affirm a state decision striking down a federal law, it would first have to interpret and enforce the Constitution.

Second, Kramer's argument against judicial review implicitly (but necessarily) relies upon an unsatisfying reading of the Supremacy Clause. The Supremacy Clause provides that:

This Constitution, and the Laws of the United States which shall be made in Pursuance thereof; and all Treaties made, or which shall be made, under the Authority of the United States, shall be the supreme Law of the Land; and the Judges in every State shall be bound thereby, any Thing in the Constitution or Laws of any State to the Contrary notwithstanding. ${ }^{20}$

By limiting supreme-law status to those federal statutes "made in Pursuance" of the Constitution, the Supremacy Clause establishes that the Constitution is superior to unconstitutional federal statutes. The Clause also vests a limited power of judicial review in state judges. When there is a conflict between the supreme law and state constitutions or laws, state judges are to enforce the supreme federal law. ${ }^{21}$

We have argued that the Supremacy Clause confirms the availability of judicial review of federal statutes. ${ }^{22}$ The Clause, by making only those federal statutes "made in Pursuance" of the Constitution part of the Supreme Law of the Land, indicates that not all federal statutes are Supreme Law. Judging which federal statutes comprise part of the Supreme Law of the Land (and are thus entitled to trump contrary state law) necessarily requires judicial review of the constitutionality of federal statutes. Hence, if state judges are to enforce the Supreme Law of the Land, they must occasionally determine the constitutionality of federal statutes, if only to determine which of these federal statutes must be allowed to trump state law.

Some, however, have criticized reliance on the Supremacy Clause using an expressio unius argument. ${ }^{23}$ As the argument goes, the Clause only authorizes state judges to refuse to enforce unconstitutional state laws. It says nothing about unconstitutional federal statutes. By negative implication, therefore, the Supremacy Clause does not authorize judicial review of federal law. This argument proves too much. To be sure, the Clause does not expressly authorize state courts to invalidate unconstitutional federal statutes. But, by the same token, the Supremacy Clause does not authorize federal courts to invalidate either federal or state law. In other words, under a strict expressio unius reading, federal courts should not be able to strike down even state laws that conflict with the Constitution, not to mention federal laws.

19 Id. $\$ 25,1$ Stat. at 85.

20 U.S. Const, art. VI, cl. 2.

21 Some of our claims about the Supremacy Clause parallel those independently made by Brad Clark in a recent article. See Bradford R. Clark, The Supremacy Clause as a Constraint on Federal Power, 71 Geo. Wash. L. Rev. 91 (2003).

22 Prakash \& Yoo, The Origins of Judicial Review, supra note 3, at 903.

23 For a discussion of this point, see Learned Hand, THE Bill of Rights 28 (1958) (making expressio unius argument), but compare Herbert Wechsler, Toward Neutral Principles of Constitutional Law, 73 HARV. L. REV. 1, 3 (1959). 
This result seems untenable and one that even the sharpest critics of judicial review, such as Professors Bickel and Choper, would be unwilling to stomach. Yet, this is the logical consequence of their narrow reading of the text of the Supremacy Clause. ${ }^{24}$ This radical result also follows from Professor Kramer's insistence on explicit, unambiguous sanction for all forms of judicial review. ${ }^{25}$ If Professor Kramer maintains his insistence on explicit, unambiguous sanction for all types of judicial review, he has to believe that both lower federal courts and the Supreme Court lack the power to review the constitutionality of state law. ${ }^{26}$

\section{B. Structure}

Professor Kramer's problems with the constitutional text are compounded by his failure to account for the constitutional structure. As Chief Justice Marshall suggested in Marbury v. Madison, ${ }^{27}$ the structure of the federal government itself dictates the existence of judicial review. Judicial review arises from two fundamental constitutional principles: the limited authority of the federal government under a written Constitution, and the coordinate status of the judiciary within the separation of powers. In other words, constitutional structure requires the federal courts to refuse to enforce unconstitutional laws in the course of performing their function of deciding Article III cases or controversies. It does not, however, make the federal judiciary's interpretations of the Constitution supreme or binding on the other, coordinate branches of government. Hence while the Constitution's structure compels judicial review, it does not establish judicial supremacy.

The Constitution is a written document in which the American people have granted limited delegations of authority to the federal government. As James Madison wrote in The Federalist No. 46, "[t] $]$ he Federal and State Governments are in fact but different agents and trustees of the people, instituted with different powers, and designated for different purposes."28 Madison reminded antifederalists that "the ultimate authority, wherever the derivative may be found, resides in the people alone." 29 When the federal government exercises authority beyond the enumerated powers in the Constitution, it acts

24 As we explain elsewhere, we believe that the reason the Framers included the direction to state judges at all was to override their existing loyalty to their state constitutions, which, after all, were the highest source of legal authority at that time for the state courts. See Prakash \& Yoo, The Origins of Judicial Review, supra note 3, at 913.

25 See Kramer, We the Court, supra note 1, at 63-64.

26 In his comment, Professor Kramer notes that there were "gaps and ambiguities and inconsistencies" in the text and this may explain why the Constitution never expressly authorizes federal court judicial review of state law. Kramer, When Lawyers Do History, supra note 1, at 401. But in making this claim, Professor Kramer retreats from his textual claim in the Harvard Law Review. See Kramer, We the Court, supra note 1. There, Professor Kramer demanded an explicit, unambiguous authorization for judicial review of federal statutes-in the absence of such text, judicial review was too controversial to be made part of the Constitution. See id. at 65-66. He now abandons that textual claim by asserting that judicial review of state statutes by federal courts is part of the Constitution notwithstanding the obvious textual gap.

27 Marbury v. Madison, 5 U.S. (1 Cranch) 137 (1803).

28 The Federalist No. 46, at 315 (James Madison) (Jacob E. Cooke ed., 1961).

29 Id. 
illegally. As Alexander Hamilton expressed it in The Federalist No. 78, "every act of a delegated authority, contrary to the tenor of the commission under which it is exercised, is void." 30 In effect, the Constitution establishes a rule of decision that places it higher than the acts of the government it creates. The Oaths Clause reflects this hierarchy, declaring that " $[t]$ he Senators and Representatives before mentioned, and the Members of the several State Legislatures, and all executive and judicial Officers, both of the United States and of the several States, shall be bound by Oath or Affirmation, to support this Constitution." ${ }^{31}$ The Oaths Clause makes clear that all officials of both the federal and state governments have a basic obligation not to violate the Constitution. Marbury suggests that the Clause might go further by requiring oath-takers to disregard governmental actions of other institutions that conflict with the Constitution. ${ }^{32}$ Article $\mathrm{V}$ also reflects this hierarchy, as the supermajority process for constitutional amendment makes clear that the normal processes of government cannot change the Constitution. ${ }^{33}$ Thus, the Constitution makes clear that officers of the government are to consider the Constitution to be superior law to the actions of the federal or state governments when acting in their normal legislative or executive functions.

The limited nature of federal power under a written Constitution interacts with a second fundamental principle - the separation of powers - to establish judicial review. The separation of powers creates three branches of government that are both equal and independent. As James Madison wrote in The Federalist No. 49, "[t]he several departments being perfectly co-ordinate by the terms of their common commission, neither of them, it is evident, can pretend to an exclusive or superior right of settling the boundaries between their respective powers." 34 Each branch is equal in the sense that each exercises grants of authority received directly from the people through the Constitution. Each branch is independent because each performs certain unique functions that the Constitution vests in it alone. As Madison wrote in The Federalist No. 48:

It is agreed on all sides, that the powers properly belonging to one of the departments, ought not to be directly and compleatly administered by either of the other departments. It is equally evident, that neither of them ought to possess directly or indirectly, an overruling influence over the others in the administration of their respective powers. ${ }^{35}$

This separation of powers prevents the "tyrannical concentration of all the powers of government in the same hands." 36

From this structure, judicial review emerges. The Constitution vests the federal courts with the core function of deciding Article III cases or controversies. In the course of performing its constitutional responsibility the judi-

30 The Federalist No. 78, at 524 (Alexander Hamilton) (Jacob E. Cooke ed., 1961).

31 U.S. Const. art. VI, cl. 3.

32 See Marbury, 5 U.S. (1 Cranch) at 180.

33 See U.S. Const. art. V.

34 The Federalist No. 49, at 339 (James Madison) (Jacob E. Cooke ed., 1961).

35 The Federalist No. 48, at 332 (James Madison) (Jacob E. Cooke ed., 1961).

36 Id. at 338. 
ciary must give primacy to the Constitution over any other actions of the federal or state governments. This requires federal judges to interpret the Constitution in the course of resolving conflicts that arise between federal or state law and the Constitution. As Alexander Hamilton wrote in The Federalist No. 78:

The interpretation of the laws is the proper and peculiar province of the courts. A constitution is in fact, and must be, regarded by the judges as a fundamental law. It therefore belongs to them to ascertain its meaning as well as the meaning of any particular act proceeding from the legislative body. If there should happen to be an irreconcileable variance between the two, that which has the superior obligation and validity ought of course to be preferred $\ldots .{ }^{37}$

It is in the course of deciding cases that judges construe the Constitution. ${ }^{38}$

The contrary view-that the Constitution forbids judicial review-would disregard these basic constitutional principles. First, the anti-judicial review position would undermine the limited nature of the Constitution by removing one of the checks on the powers of the other branches. The Founders were concerned that the legislature would become the judge of its own powers, which they believed would lead Congress to exercise unwarranted and potentially unlimited powers. This is not to say that the political process does not operate to protect federalism; we agree with Professors Wechsler and Choper that the composition of the Senate and the structure of the elections for the House of Representatives and the president favor state interests. ${ }^{39}$ But, nowhere does the constitutional text and structure compel the conclusion that the political safeguards of federalism are the exclusive protections for federalism. By embedding protections for federalism in the structure of the political process and by establishing judicial review, the Founders simply created a double safeguard to protect against an overweening central government. ${ }^{40}$

Second, the anti-judicial review position singles out federalism for disfavored treatment, when there is no justification for such a result in the constitutional text or structure. Professors Kramer and Choper, for example, believe that judicial review must exist to protect individual rights but not

37 The Federalist No. 78, supra note 30, at 525.

38 Marbury v. Madison, 5 U.S. (1 Cranch) 137, 177 (1803).

39 See ChOPER, supra note 10, at 80-81, 184-90; Wechsler, supra note 11, at 559.

40 We think that Professor Kramer has over-read our criticism of his argument. In his comment, he argues that we have myopically focused on the narrower question of whether judicial review was understood to be the primary method of enforcing the Constitution, and that we have overlooked the historical evidence that Americans at the Founding believed that there were many methods for enforcing the Constitution, including mobbing, political actions, and so on. Kramer, When Lawyers Do History, supra note 1, at 399. We have never argued that judicial review was the only means of enforcing the Constitution, or that it was even a primary means. In other work that came even before our extended exchanges with Professor Kramer, one of us made only the limited argument that judicial review is only one of many safeguards of the Constitution, and indeed not even the primary one. See generally Yoo, The Judicial Safe. guards of Federalism, supra note 3, at 1381. What we have criticized Professor Kramer for, however, is his absolutist argument that judicial review was completely excluded as a method of enforcing the Constitution. 
federalism. ${ }^{41}$ Nothing in the constitutional text, however, establishes that judicial review extends to some parts of the Constitution but not to others. In fact, given Professor Kramer's claim that the Framers did not originally understand judicial review to even exist, it seems utterly contradictory to then claim, as he does, that judicial review should continue as a means of protecting individual rights. ${ }^{42}$ If judicial review is conceded to exist, then it must exist over federalism questions as well as individual rights-there is no textual exception for federalism questions. Indeed, for the first few years of the Republic there was no bill of rights, and hence judicial review must have extended primarily to questions about the limits of the powers of the federal government.

Third, the arguments of Professor Kramer and others single out the judiciary as the one branch (indeed, the one entity) that cannot interpret and enforce the higher law of the Constitution. No one disputes that the president may veto bills that he believes to be unconstitutional, nor does anyone argue that Congress cannot reject bills it believes to be unconstitutional. Moreover, Kramer also claims that juries can judge the constitutionality of federal statutes. ${ }^{43}$ Indeed, much of Professor Kramer's project involves exalting the people's role in interpreting and enforcing the Constitution. ${ }^{44}$ Yet, under his anti-judicial review thesis, federal judges are burdened with a unique disability, compelled to enforce unconstitutional laws when their colleagues in the coordinate branches are not. It is far from obvious why it is acceptable for the executive to second-guess the legislature (when deciding to veto a bill or enforce a statute) and thus act as an "interloper," 45 but impermissible for judges to play the same role. In both situations, one agent of the people checks another. Nothing in the constitutional text or structure mandates such a perverse, asymmetrical allocation of power. Indeed, such an allocation would damage the separation of powers by undermining the independence of the judiciary and its ability to resist the encroachments of the other branches.

\section{The Constitution as Judicially Enforceable Law}

At various points in his Harvard Law Review article, Professor Kramer claims that the Constitution was a "special kind of fundamental law."46 While supreme and binding, "[r]esponsibility for its interpretation and enforcement lay with the people themselves." 47 Through voting, petitioning, pamphleteering, and, if need be, mobbing, the people were to defend the constitutional order. ${ }^{48}$ In contrast, judges "had no role interpreting or enforcing fundamental law." 49 Indeed, "[c]ourts simply had nothing to do with"

41 See generally Kramer, We the Court, supra note 1, at 166; CHOPER, supra note 10, at 169.

42 Kramer, We the Court, supra note 1 , at 166.

43 Id. at $31-32$.

44 See id. at 16-74 (discussing Popular Constitutionalism).

45 Id. at 49.

46 See, e.g., id. at 163.

47 Id. at 26.

48 Id. at $26-28$.

49 Id. at 26. 
judging the constitutionality of legislation and "were acting as interlopers if they tried to second-guess the legislature's decision."50 According to Kramer, constitutions of the Eighteenth Century are best described as "political-legal" documents, ${ }^{51}$ a category largely unfamiliar to Twenty-First Century readers who assume that any law must be judicially enforceable.

At the same time, Professor Kramer embraces the conventional view that the Constitution was to be judicially enforced against the states. In the form of the Supremacy Clause, claims Kramer, the "Framers clearly decided to adopt judicial review as a device for controlling state laws." 52 Kramer finds "striking" the supposed absence of similarly explicit language authorizing judicial review of federal statutes. ${ }^{53}$

Professor Kramer's claims about the original conception of our Constitution are problematic. Whatever may have been true for constitutions of the early Eighteenth Century, by the time of the late 1780s, Americans were coming to regard their constitutions as fundamental law applicable by courts. ${ }^{54}$ Most relevant, people who addressed this precise issue with respect to the federal Constitution universally agreed that judges would interpret and defend the Constitution in the course of deciding cases, even in cases involving federal legislation.

To begin with, many people in the 1780 s regarded state constitutions as judicially enforceable fundamental law. In state court cases ${ }^{55}$ familiar to the

\footnotetext{
50 Id. at 49.

51 Id.

52 Id. at 61.

53 Id. at 64.

54 See infra note 55.
}

55 See, e.g., Josiah Philips's Case (Va. 1778) (refusing to enforce a bill of attainder prohibited by the state constitution), discussed in St. George Tucker, 1 Blackstone's Commentaries: With Notes of Reference to the Constitution and Laws of the Federal Government of the United States and of the Commonwealth of Virginia app. at 293 (Lawbook Exchange 1996) (1803); Holmes v. Walton (N.J. 1780) (holding that a law allowing trial by a jury of six individuals violated the state constitution), described in Austin Scott, Holmes vs. Walton: The New Jersey Precedent: A Chapter in the History of Judicial Power and Unconstitutional Legislation, 4 AM. Hist. REv. 456, 456-60 (1899); Commonwealth v. Caton, 8 Va. (4 Call) 5,20 (1782) (holding invalid a pardon passed by one house of the state legislature and rejected by the other); Rutgers v. Waddington (NY City Mayor's Ct. 1784) (interpreting the Trespass Act to avoid conflict with the law of nations and the peace treaty between the United States and Great Britain), reprinted in 1 The Law Practice of Alexander Hamilton: Documents and Commentary 392, 414-19 (Julius Goebel, Jr. et al. eds., Columbia Univ. Press 1964); Symsbury Case, 1 Kirby 444 (Conn. Super. Ct. 1785) (holding that the legislature could not alter a land grant without the grantees' consent); Trevett v. Weeden (R.I. 1786) (refusing jurisdiction where law required action to be tried by a judge in the face of fundamental law guaranteeing trial by jury), described in James M. Varnum, The Case, Trevett Against Weeden: On Information and Complaint, for Refusing Paper Bilis in Payment for Butcher's Meat, in Market, at Par with Specie (1787); Ten-Pound Act Cases (N.H. 1786) (holding that a statute that required small debt claims to be tried by a justice of the peace violated the state constitution's guarantee of trial by jury), described in William W. Crosskey, 2 Politics AND the ConSTITUTion IN THE History OF THE UNITEd States 968-71 (1953); Bayard v. Singleton, 1 N.C. (Mart.) 48 (1787) (holding that a statute directing courts to dismiss on a party's motion actions brought to recover lands sold under another act violated the state constitution's guarantee of trial by jury). 
Founders, ${ }^{56}$ state courts had enforced state constitutions by nullifying unconstitutional laws. Hence, state courts did not treat state constitutions as if they were non-judicially enforceable fundamental law. Likewise, commentators outside the courts understood that judges could engage in judicial review of state statutes. ${ }^{57}$ Although some state legislators attempted to censure state judges for their refusal to enforce state statutes, these attempts uniformly failed. On the whole, state legislatures seemed to agree that state courts could refuse to enforce unconstitutional state statutes.

As noted earlier, the Founders were aware of these cases and at least some approved of the state courts' ability to interpret and enforce the state constitutions. The Supremacy Clause reflects this general acceptance, as it assumes that state constitutions are judicially cognizable law. ${ }^{58}$ By listing state constitutions as a set of laws that must give way to supreme federal law, the Founders recognized that courts would interpret state constitutions and judge whether such constitutions conflicted with federal law. After all, if the state courts could not interpret the state constitutions, there would be no need for the State Judges Clause to proclaim that federal law must trump the state constitutions. ${ }^{59}$

All this suggests that in 1787 , the state constitutions were not generally regarded as political-legal documents. Given this background of state court enforcement of state constitutions and given the lack of an affirmative statement in the Constitution prohibiting courts from enforcing the federal constitution, there is little reason to believe that the Founders regarded the federal Constitution as a political-legal document, unenforceable by the courts. Indeed, as we discuss later, dozens of Founders confirmed that the Constitution was judicially enforceable.

Another reason to doubt Professor Kramer's claims about the status of the Constitution arises from his inconsistency on the Constitution's judicial enforceability. Professor Kramer, ${ }^{60}$ along with other proponents of a political-legal Constitution, such as Robert Clinton ${ }^{61}$ and Sylvia Snowiss, ${ }^{62}$ admit that the federal Constitution was ordinary law to be applied vis-à-vis the states. If a court is presented with a claim that some state statute violates the federal Constitution, the court cannot just proclaim that the Constitution is a political-legal document. Rather, the court must interpret and enforce the Constitution. Hence, it follows that the Constitution cannot be a purely political-legal document. Either Professor Kramer must abandon his claim about the political-legal nature of the Constitution or he must deny that the Constitution is enforceable against the states.

Faced with this unhappy choice, Professor Kramer might be tempted to claim that the Constitution is sometimes a political-legal document and that it

\footnotetext{
56 See Prakash \& Yoo, The Origins of Judicial Review, supra note 3, at 934-39.

57 Id. at 891 .

58 U.S. Const. art. VI, cl. 2.

59 Prakash \& Yoo, The Origins of Judicial Review, supra note 3, at 910.

60 Kramer, We the Court, supra note 1, at 63-64.

61 See, e.g., Robert L. Clinton, Marbury v. Madison and Judicial Review (1989).

62 See, e.g., Sylvia Snowiss, Judicial Review and the Law of the Constitution 2
} (1990). 
is sometimes ordinary, judicially enforceable law. Yet there is no textual or historical reason to suppose that the federal Constitution is schizophrenic. Indeed, seemingly unaware that he has adopted inconsistent positions, Professor Kramer has done nothing to support the complicated claim that the Constitution is a bipolar document.

More generally, once one admits that the Constitution is enforceable against the states, it becomes impossible to conclude that any part of the Constitution is a political-legal document. If the courts are to ensure the Constitution's supremacy vis-à-vis the states, they must stand ready to interpret the entire Constitution. After all, plaintiffs seeking to strike down state law can cite many sections and clauses from the Constitution (besides Article I, section 10) to support their claims. It follows that no part of the Constitution can be understood as political-legal and, therefore, judicially unenforceable.

Given the implausibility of the political-legal argument, it is hardly surprising that apparently no one during the ratification and post-ratification periods ever claimed that the Constitution was a political-legal document. Obviously, we do not mean that no Framer ever used the phrase "politicallegal" document during the Philadelphia or state ratifying conventions, as Professor Kramer characterizes our argument. ${ }^{63}$ Rather, our claim is that no one during the ratification struggle argued that federal and state courts could not interpret and enforce the Constitution. Put another way, no one argued that popular constitutional methods (voting, petitioning, mobbing) were the exclusive safeguards. In the face of dozens of Founders who affirmed the availability of judicial review of federal statutes (we discuss this evidence later), ${ }^{64}$ it is telling that Professor Kramer cannot cite even one who objected that the Constitution is a special type of non-judicially cognizable law.

We are not arguing that the concept of a political-legal document is incoherent or impossible. We merely claim that, at the Founding, the Constitution was not understood or regarded as a non-judicially enforceable politicallegal document. Additionally, we argue that Professor Kramer cannot possibly believe that courts could not interpret and defend the federal Constitution because he accepts that judges could enforce the Constitution vis-à-vis the states.

Put simply, we believe that Professor Kramer has failed to corroborate his ambitious claim, the one pressed in his Columbia Law Review and Harvard Law Review articles, ${ }^{65}$ if not in his as yet unpublished book, that the Constitution does not authorize judicial review. In order to prove this negative, and in light of the numerous instances when judicial review was discussed as a constitutional feature, we would have expected Professor Kramer to point to at least one exchange where someone denied that the judiciary could enforce the Constitution. We address these and other problems with Professor Kramer's use of history next. ${ }^{66}$

\footnotetext{
63 Kramer, When Lawyers Do History, supra note 1, at 399.

64 See infra Part IV.

65 See supra note 1.

66 See infra Part III.
} 


\section{Historical Methodology}

Before we discuss Professor Kramer's particular historical claims, some general comments on his historical method are appropriate. To begin with, we question Professor Kramer's "quantitative" historical methodology. His articles repeatedly belittle the evidence for judicial review by claiming that the amount of evidence opposed to his thesis is small if nonexistent. At one point he says there is but a "smattering" of evidence in favor of judicial review; ${ }^{67}$ at another point, he dismisses the evidence as "paltry." 68 In making these arguments, Professor Kramer misunderstands the nature of historical inquiry. History is not like a trial, in which evidence is simply accumulated until one side of the scale ("pro") is higher than the other side ("con"). Rather, there is what we might call a "qualitative" element to the study of history, in which scholars must be sensitive to the broader intellectual picture of the Founding period and the secondary work of historians about the period.

Recent work by two of the leading intellectual historians of the early national period, Professors Jack Rakove and Gordon Wood, ${ }^{69}$ indicates that the Framers came to accept judicial review during the period between independence and ratification. This was not the result of a few well-placed speeches or pamphlets, as Professor Kramer at times seems to demand, but of important long-term developments in American political and constitutional thought. As Professor Wood has observed, "The sources of something as significant and forbidding as judicial review never could lie in the accumulation of a few sporadic judicial precedents, or even in the decision of $\mathrm{Mar}$ bury $v$. Madison, but had to flow from fundamental changes taking place in the Americans' ideas of government and law."70 Professor Rakove argues that judicial review became an important response to widespread dissatisfaction with changes in the American governmental system, particularly the weakness of national authorities, the explosion of legislation, and more positive popular attitudes toward the judiciary. ${ }^{71}$

While it would be almost impossible to match these developments to exact dates, they clearly show that the broader cycle of American constitutional and political history during the Founding period supports a reading of the primary materials in favor of judicial review. For the Framers to have subscribed to Kramer's idiosyncratic account, they would have had to have acted counter to the great tide of constitutional history. ${ }^{72}$ Professor Kramer has provided no compelling reason to explain why the Framers' thinking on

67 See Kramer, We the Court, supra note 1, at 72.

68 Id. at 71.

69 See Gordon S. Wood, The Origins of Judicial Review Revisited, or How the Marshall Court Made More Out of Less, 56 WAsH. \& LeE L. Rev. 787, 793 (1999).

70 Id.

71 Jack N. Rakove, The Origins of Judicial Review: A Plea for New Contexts, 49 STAN. L. REv. 1031, 1055-56 (1997).

72 For a discussion of the problems with reading primary sources in this manner, compare John C. Yoo, Clio at War: The Misuse of History in the War Powers Debate, 70 U. Colo. L. Rev. 1169 (1999), with William M. Treanor, Fame, the Founding, and the Power to Declare War, 82 Cornell L. Rev. 695, 721 (1997). 
judicial review of federal statutes would not parallel the broader historical trends of the time. Indeed, Professor Kramer does not even adequately explain why the Framers followed those trends once-with respect to judicial review of state law-but supposedly bucked these trends with respect to judicial review of federal statutes. Instead, as we discuss later, Professor Kramer's narrative treats judicial review of federal statutes as if it were subject to sudden post-ratification revolution, rather than to more gradual changes in the political thought of the time. ${ }^{73}$

Another difficulty with Professor Kramer's claims is his lack of any analysis of the legal acumen and political standing of those Founders who confirmed that the Constitution authorized judicial review. When trying to piece together the meaning of, and intent behind, some ancient document, surely it matters not only how many times something was said, but also who said it. Hence, even if Professor Kramer deems the quantity of evidence insufficient, he must account for the quality of evidence, in this case the high preponderance of prominent jurists, legislators, and governors who agreed that the Constitution authorized judicial review. Those who believed that the Constitution authorized judicial review of federal statutes included James Wilson, James Madison, Alexander Hamilton, Patrick Henry, Samuel Adams, Luther Martin, and dozens of others. These were not political naifs, unfamiliar with interpretation of the law or the workings of state government. The list includes governors, state legislators and judges, attorneys general, and future presidents, senators, and chief and associate justices. Rather than quickly dismissing the evidence as insufficient, Professor Kramer must explain why so many brilliant legal thinkers of that period woefully misread the Constitution.

One might view Professor Kramer's historical arguments as suffering from a level-of-generality problem. He claims that the Framers simply did not talk about judicial review all that much, especially when compared with the broader issue of federalism, or the new government's taxation and spending powers, or the need for guarantees of individual rights. That is only an attempt, however, to define the issue at a fairly abstract level of generality. If we view the question as what methods of constitutional enforcement would exist, certainly discussions of popular constitutionalism would constitute a fairly important portion of the ratification evidence. When we confine our inquiry to a narrower question, such as discussion of a specific method of constitutional enforcement, naturally the historical evidence will be smaller in amount. Perhaps if we were arguing that judicial review was the primary or, indeed, the only method for enforcing the Constitution, then Professor Kramer's claim that we have slighted the popular means of enforcement would have some weight. But if the Founders conceived of judicial review, as we have argued, as a secondary, but not exclusive check on unconstitutional action, and indeed, not even all that remarkable in light of the practice of the state courts and the understanding of the judicial role at the time, then the amount of evidence one would expect need not be all that high. Professor Kramer, nevertheless, fails to even engage the issue by mistaking discussion

73 See infra Part IV.D. 
of one method of constitutional enforcement as a sign that the Founders considered all others to be excluded.

Finally, Kramer adopts an exclusively quantitative approach without specifying his quantitative methodology. He strikingly claims that the historical evidence is quantitatively insufficient without any reference to the metric used. Yet, to credibly claim that there is not enough evidence Professor Kramer must have some theory of how much evidence is enough. Simply declaring that the available support is "paltry" without explaining what standard is being employed leaves too many questions unanswered and raises the specter of double standards at work. While Professor Kramer assures that there is "huge" evidence in favor of popular constitutional safeguards, he tells us "judicial review was a small matter of little apparent interest or significance." " $\mathrm{He}$ even tells us that it would be a "waste of time" to compare the materials. ${ }^{75}$ We have read Professor Kramer's previous articles and the underlying primary and secondary materials. Suffice it to say that we do not share his impression that one set of materials vastly exceeds the other.

The inescapable problem with Professor Kramer's claims is that, although he deems the evidence that the Constitution authorized judicial review as woefully insufficient and lacking, he never adequately explains why. That there might be less evidence in favor of judicial review than of something else (like criticism of the absence of a bill of rights) is interesting, but not dispositive. One can always find another topic that was discussed more often and deem some other topic "insignificant". in comparison. To avoid the reductio where only one constitutional issue is deemed decided (because it was discussed the most), one must establish some standard to establish the Constitution's meaning (either its original intent or its original public meaning) on a particular point. Professor Kramer fails to provide such a standard.

Perhaps Professor Kramer believes that he can safely dismiss the available evidence because he compares it to the total mass of Founding materials. Indeed, The Documentary History of the Ratification of the Constitution, the definitive compilation of Founding-era records, is seventeen volumes and growing. This standard, however, uses the wrong denominator. For every particular constitutional issue, there is often very little on point in these materials. That is because most newspaper discussions of the Constitution were little squibs, often a paragraph or two long; a two or three-page discussion is the exception. By their nature, most of these discussions of the Constitution were rather superficial and unilluminating about many significant matters. Likewise, the convention records, when they exist, were debates on the entire Constitution. There were so many issues to discuss-the scope of legislative power, the executive power, the protection of individual rights, the division of state and federal power, and so many others-that there is a (relative) paucity of materials on each one. If we were to require that the original understanding of a provision cannot be "proven" unless it was discussed in a certain percentage of the pages of The Documentary History of the Ratification of the Constitution, then we can say very little about the Constitution's

74 Kramer, When Lawyers Do History, supra note 1, at 409-10.

75 Id. at 410. 
original understanding, other than that it is completely unknown. If that were Professor Kramer's argument, his articles could have begun and ended with the familiar (and unconvincing) claim that the Constitution's original understanding is simply unknowable.

In any event, even if we agreed with Professor Kramer's volumetric approach, the amount of historical evidence concerning judicial review should surely surpass any reasonable standard for demonstrating the original understanding. All indicators of original meaning and original intent point in the same direction. First, several state courts had begun to establish judicial review prior to the Philadelphia Convention and the state courts had exercised such authority even in the absence of clear textual authorization. ${ }^{76}$ Second, more than a dozen Philadelphia delegates (in almost two-dozen instances) assumed that the courts could refuse to enforce unconstitutional federal legislation. ${ }^{77}$ Third, during the ratification fight almost three-dozen individuals affirmed that the Constitution authorized the federal and state courts to ignore unconstitutional federal legislation. ${ }^{78}$ Fourth, Federalists and antifederalists made these affirmations throughout the state ratifying conventions and in the public press. ${ }^{79}$ Finally, everyone who has studied the issue (including Professor Kramer) has concluded that there was a post-ratification consensus that the Constitution authorized judicial review of federal legislation. ${ }^{80}$ And on top of all of this history, there is ample textual and structural support for the notion that the Constitution authorizes judicial review of federal legislation. ${ }^{81}$ Arrayed against all this evidence, neither Professor Kramer nor anyone else has ever been able to cite anyone from the Founding era who denied that the Constitution authorized judicial review of federal legislation. Hence, even if one wanted to employ a quantitative approach to the original understanding, the numbers speak for themselves.

\section{What the Founders Actually Said About Judicial Review}

We already have detailed our more general, methodological concerns with Professor Kramer's historical claims. Here, we consider some of his more precise claims. If we are to believe Professor Kramer, we must conclude that quite a few of the best lawyers and most prominent statesmen of the Founding era were absolutely wrong when they read the Constitution as authorizing judicial review of federal statutes. And we must believe that the opposite view-that the Constitution did not authorize judicial review-was the more conventional view even though no one apparently voiced it. In other words, Kramer's arguments suggest the existence of a silent majority of Founders who, though confronted with numerous claims that the Constitution authorized judicial review, apparently never uttered a peep in dissent. Needless to say, we think all of this is rather unlikely.

\footnotetext{
76 See infra Part IV.A.

77 See infra text accompanying notes $108-11$.

78 See infra Part IV.B.

79 See infra Part IV.C.

80 See infra Part IV.D.

81 See supra Part I.
} 


\section{A. Judicial Review Prior to Philadelphia}

Professor Kramer's recounting of the years leading up to Philadelphia suggests that judicial review was wholly obscure, unformed, and controversial. $^{82}$ We believe that he is mistaken. In fact, during this period, judicial review came to be an accepted, even important, check on the legislative power and its tendency to overleap constitutional constraints.

In the $1780 \mathrm{~s}$, state courts from across the nation engaged in judicial review ${ }^{83}$ striking down state statutes that violated state constitutions, written and unwritten. Even where courts did not actually ignore unconstitutional statutes, they were perceived as having creatively interpreted state statutes to avoid judging them unconstitutional. In a sense, some courts employed an early form of the doctrine of avoidance in order to evade having to judge the constitutionality of state statutes.

Though Professor Kramer notes the existence of these cases, he greatly overstates the opposition to them, particularly the legislative opposition. ${ }^{84}$ Notwithstanding scattered opposition, more people than Kramer cares to admit acknowledged that the courts were authorized to judge the constitutionality of acts. Indeed, it is particularly telling that some legislatures apparently conceded that the courts could judge the constitutionality of state statutes.

Consider Professor Kramer's treatment of the reaction to Trevett v. Wee$d_{e n}{ }^{85}$ in Rhode Island. He cites the negative reaction to the case as representative of the adverse reaction to judicial review in the $1780 \mathrm{~s}^{86}$ The governor convened a special meeting of the state legislature at which the Rhode Island judges were to account for their actions. ${ }^{87}$ Kramer contends that the "judges' courage gave way completely, and they meekly submitted a written memorial" disavowing the right to ignore the legislature's laws. ${ }^{88} \mathrm{He}$ also notes that after a failed impeachment attempt, the legislature chose to reappoint only one of the judges. ${ }^{89}$

Unfortunately, Kramer's discussion of the Rhode Island reaction omits important facts. First, Professor Kramer discovers a concession where none was made. He paraphrases the judges as claiming no right to control the legislature's laws and hence abjuring judicial review. Yet, the judges never renounced judicial review. Instead, they only denied any power over the legislature's "constitutional laws." 90 This claim is entirely consistent with a continued belief in judicial review. Moreover, Professor Kramer fails to reveal that the legislature subsequently repealed the statute in question, thereby

82 See Kramer, We the Court, supra note 1, at 59-60.

83 See supra note 55.

84 See Kramer, We the Court, supra note 1, at 32-59.

85 Trevett v. Weeden (R.I. 1786), described in VARNUM, supra note 55.

86 See Kramer, We the Court, supra note 1, at 58 ("Similar reactions [to that in Rhode Island] were recorded throughout the 1780 s whenever and wherever a court considered exercising review, with the exception of Virginia.").

87 See id. at 57.

88 Id. at 58.

89 Id.

90 Trevett, described in VARNuM, supra note 55, at 35. 
suggesting that the legislature might have agreed with the court about the statute's unconstitutionality. ${ }^{91}$

His treatment of other reactions is similarly troubling. Playing up the opposition to judicial review, Professor Kramer notes that the New Hampshire legislature considered impeachment for the judges involved in the Ten Pound Cases.92 And he notes that initially the legislature persisted in believing that the acts in question were constitutional. ${ }^{93}$ Regrettably, Professor Kramer omits that the legislature, by a margin of three to two, eventually concluded that the judges were "not Impeachable ... as their conduct [was] justified by the constitution." 94 It would seem that the legislators had a change of heart and that they agreed that judicial review was "justified by the constitution." 95

Finally, Professor Kramer does not recount how other legislatures also made admissions against interest, acknowledging that judges could engage in judicial review. By a margin of two to one, North Carolina legislators rejected a proposal that required statutes and the state constitution to be on an equal footing. ${ }^{96}$ Although a committee charged the North Carolina judges who decided Bayard v. Singleton with "disregarding or suspending" the legislature's acts, a subsequent committee concluded that these judges had done nothing wrong. ${ }^{97}$

Consistent with our claim that judicial review only faced scattered oppositions, we know of no judge who was either impeached or censured for engaging in judicial review. Indeed, in most states, there was nothing even resembling legislative retaliation. Rhode Island may have been the lone exception to the pattern of legislative acquiescence to judicial review. But even there, the Rhode Island legislature did not dismiss, fine, or imprison the judges. ${ }^{98}$ Instead, the legislature, apparently without explanation, exercised its constitutional authority to refuse reappointment to all but one of the judges. ${ }^{99}$ We know of no evidence that judicial review played a role in the reappointment decision. Even this mild rebuke-if that is what it was-was condemned. During the Philadelphia Convention, Madison criticized Rhode Island for replacing the judges with others "who would be willing instruments of the wicked \& arbitrary plans of their masters." 100 Despite the fact that the Rhode Island Charter nowhere specifically authorized judicial review, no one rose to defend the Rhode Island legislature.

91 See Charles G. Haines, The American Doctrine of Judicial Supremacy 111 (1959) ("Before the new judges took their seats, however, the obnoxious law was repealed and the courts had gained a partial victory.").

92 Kramer, We the Court, supra note 1, at 57.

93 Id.

94 William W. Crosskey, Politics and the Constitution in the History of the UnITED STATES 970 (1953).

95 Id. at 970 .

96 Id. at $970-71$.

97 Id. at $971-72$.

98 See Kramer, We the Court, supra note 1 , at 57.

99 Id.

100 See 2 The Records of the Federal Convention of 1787, at 28 (Max Farrand ed., 1911). 
The evidence suggests that, by the time of the Constitution's drafting, the political elite generally had accepted judicial review. Several courts either had engaged in judicial review or were perceived as having successfully done so. ${ }^{101}$ Outside of the courts, many understood judicial review as a beneficial check on legislative power. ${ }^{102}$ While there was some opposition, the opposition was swimming against the tide of history. We thus disagree with Professor Kramer's conclusion that "[t]hose who rejected judicial nullification were plainly in the ascendant, as their position more closely conformed to conventional wisdom and expectations" 103 and his surprising claim that it was not "even clear" what judicial review was all about. ${ }^{104}$ As subsequent events would show (even in Professor Kramer's own account), those opposed to judicial review were clearly fighting a losing battle and, significantly, no one ever questioned the meaning of judicial review when others repeatedly acknowledged that the Constitution authorized it.

\section{B. Judicial Review at Philadelphia}

Surveying the records of the Philadelphia Convention, Kramer quickly concludes that the Framers codified judicial review of state law in the form of the Supremacy Clause. ${ }^{105}$ They thereby "answered the leading objection to judicial review"-that it was unauthorized. ${ }^{106}$ Although there were some delegates who seemed to assume judicial review of federal statutes, most "probably had not given the idea much thought," claims Kramer. ${ }^{107}$ More importantly, the handful of supporters of such judicial review never took the necessary step of proposing the power of judicial review, a failure made "striking" by the inclusion of the Supremacy Clause. ${ }^{108}$

At first blush, Professor Kramer's treatment of judicial review of state law seems wholly familiar and unobjectionable. Most everyone agrees that the Constitution authorizes judicial review of state law. Yet, Kramer's previous claims about judicial review being controversial and obscure do not jibe well with his claims here. Just two pages before asserting that the Convention clearly incorporated judicial review of state law, ${ }^{109}$ Kramer claims that it was not even clear what judicial review was. ${ }^{110} \mathrm{He}$ also claims that those opposed to judicial review were "ascendant." 111 If that was so in 1787, prior to Philadelphia, how did the Framers incorporate judicial review without any significant discussions or explanations of the supposedly obscure and controversial institution? Professor Kramer offers no explanation for how those in ascendance (those opposed to judicial review) suddenly lost ground to those

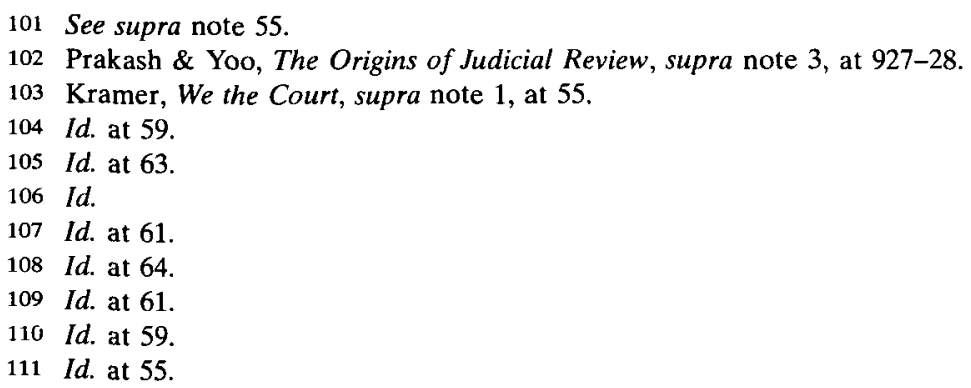


who favored it as a check on legislatures. Nor does he explain how the Framers incorporated something almost wholly unknown to them.

Moreover, if Professor Kramer is correct that the "leading objection"112 to judicial review was that it was unauthorized, he cannot account for federal court judicial review of state law. As we noted earlier, the Supremacy Clause only authorizes judicial review by state courts; it does not authorize judicial review of state law by federal courts. Hence, if the leading objection to judicial review was that it was unauthorized, and if the Supremacy Clause is the only provision that speaks to judicial review (as Professor Kramer supposes), there is no authority for the Supreme Court or the lower federal courts to engage in judicial review. As we noted earlier, the logic of Kramer's textual claims leads to the odd conclusion that only state courts can engage in judicial review of state law.

Professor Kramer's discussion of judicial review of federal statutes is even more troubling. To his credit, he acknowledges that numerous delegates assumed that courts could judge the constitutionality of federal statutes. ${ }^{113} \mathrm{He}$ intimates that these delegates were a vocal minority opposed by a silent majority. ${ }^{114}$ Professor Kramer claims that this vocal minority decided against making a futile motion to codify judicial review. ${ }^{115} \mathrm{He}$ also speculates that even if the motion somehow succeeded, the inclusion of judicial review would have jeopardized ratification. ${ }^{116}$ "One thing is certain"; delegates did not refrain from proposing a codification of judicial review "because everyone, or even a majority, agreed that the power was necessarily implicit and so nothing needed to be said."117

The evidence is stacked against these claims. Of course, we disagree with the premise of Professor Kramer's discussion-his assertion that the Constitution's text did not codify judicial review of federal statutes. But putting aside this textual disagreement for a moment, there is too much evidence that he cannot explain away. More than a dozen delegates favorably discussed judicial review of federal statutes, usually treating it as an assumed authority of the federal judiciary. ${ }^{118}$ There is no basis for believing that these delegates, who included statesmen such as James Wilson, Elbridge Gerry, Luther Martin, George Mason, and James Madison, were in the minority of the fifty-five delegates. ${ }^{119}$ If we are to judge delegates' views about judicial review by what they said before, during, and after the Convention, the tally in favor of judicial review is quite lopsided. ${ }^{120}$ The Convention records provide

\footnotetext{
112 Id. at 63.

113 Id. at 60 .

114 Id. at 60-61.

$115 \mathrm{Id}$. at 67.

116 Id.

117 Id. at 66-67.

118 Prakash \& Yoo, The Origins of Judicial Review, supra note 3, at 952.

119 Id. at 954.

120 See Raoul Berger, Congress v. The Supreme Court 104 (1969) (claiming that twenty-six delegates favored judicial review and that six opposed it); see also ChARLEs A. Beard, The Supreme Court and the Constitution 68-73 (1912) (asserting that tally was twenty-five to three).
} 
no reason to believe that there was a silent majority of delegates (or, more importantly, a majority of states) who secretly opposed judicial review.

Given the state of the record, it is extremely unlikely that delegates never proposed codification of judicial review because they feared they would lose a vote in the Convention. To the contrary, delegates had little to fear from a vote on judicial review. Given the expressed sentiments, delegates in favor of judicial review should have been relatively confident of success. More generally, delegates repeatedly proposed institutions and powers knowing full well that the Convention might reject such proposals. Kramer supplies no evidence or reason why delegates would be especially fearful of losing this particular vote.

Equally unlikely is Kramer's claim that delegates did not propose judicial review of federal statutes because they feared that its inclusion would jeopardize ratification. To begin with, Professor Kramer presents no evidence to suggest that the Framers thought strategically about this issue out of concern about its reception by the state ratification conventions. In fact, as we shall see, during the ratification fight, dozens of statesmen read the Constitution as authorizing judicial review. Yet, there was no ensuing controversy or uproar. Indeed, antifederalists often praised judicial review of federal statutes, but claimed that federal judges would not exercise it with sufficient independence and vigor. ${ }^{121}$ On the other hand, there would have been a great deal of controversy had the Constitution been understood the way Professor Kramer reads it. An asymmetric judicial review, in which the judiciary was to restrain the states, but Congress usually would be the ultimate judge of its own powers, would have played into antifederalists' attacks. Because there was no group of "nationalists" who objected that the federal government should have been more unconstrained, it is hard to see how anyone possibly could have thought that the inclusion of judicial review of federal statutes would jeopardize ratification. We are afraid that on this point, it is Professor Kramer who has projected his Twenty-First Century way of thinking about judicial review onto the minds of the Framers.

Repeatedly, Professor Kramer downplays the evidence arrayed against his thesis. Consider his discussion of the Council of Revision. ${ }^{122}$ It seems clear from the primary sources that one of the principal reasons that the delegates rejected the proposal for a combined presidential-judicial body that could veto legislation is that the judges, in exercising judicial review, already could ignore unconstitutional statutes. Luther Martin, who successfully led the effort to defeat the Council, noted that "as to the Constitutionality of laws, that point will come before the Judges in their proper official character. In this character they have a negative on the laws. Join them with the Executive in the Revision and they will have a double negative."123 Gerry and King agreed with Martin that the judiciary did not need two checks, judicial review and a share in the veto. ${ }^{124}$ Leading delegates, such as Wilson, Madison, and

121 Prakash \& Yoo, The Origins of Judicial Review, supra note 3, at 963 (discussing Virginia antifederalists' views on judicial review).

122 See Kramer, We the Court, supra note 1, at 65-66.

1232 The Records of The Federal Convention, supra note 100 , at 76 .

1241 id. at $97,109$. 
Mason, insisted that the council was still necessary in order to give the judiciary the ability to invalidate laws on policy, as well as constitutional, grounds. ${ }^{125}$ The Convention ultimately rejected the joint negative probably based in part on the notion that it was unnecessary for judges to have two safeguards, judicial review and a share in the veto. This decision was an important moment in the Federal Convention, and it shows how the shared understanding of judicial review was so strong that it affected the delegates' decision on other, related questions of governmental structure. Professor Kramer, nevertheless, inexplicably claims that it "is difficult to know what to make of" these exchanges. ${ }^{126}$ It is difficult to know what is so unclear about this well-known debate over judicial review. Delegates assumed the existence of judicial review and made decisions on that basis. ${ }^{127}$

The Council of Revision was hardly singular in this regard. Throughout the Convention, delegates cited judicial review as a reason to oppose some institutions and as a reason to support others. Gouverneur Morris cited judicial review as a reason to oppose state legislative ratification of the Constitution, ${ }^{128}$ while James Madison ${ }^{129}$ and Hugh Williamson ${ }^{130}$ cited judicial review as reasons to support popular ratification and the Ex Post Facto Clause, respectively. Despite Professor Kramer's insistence that judicial review was

1252 id. at $73-74,78$.

126 Kramer, We the Court, supra note 1, at 66.

127 Perhaps recognizing that the discussion of the Council of Revision poses problems for his claim, Professor Kramer changes tack, arguing that some delegates had a narrow concept of judicial review. Following the arguments made by Professor Crosskey and others, Professor Kramer suggests that some understood judicial review as a narrow, "defensive power limited to laws regulating the judicial process." Id. at 61. To begin with, Kramer has not provided any reason to think that the Framers would have believed that the judiciary's duty to refuse to enforce unconstitutional laws extended only to statutes that violated Article III, but not Articles I, II, IV, V, or VI. To read the Council of Revision discussion as so limited, one would have to adopt overly cramped readings of what delegates actually said. No delegate ever said that courts could engage in judicial review only as to laws regulating the courts. Moreover, each of the delegates whom Kramer claims understood judicial review quite narrowly subsequently embraced the conventional, general concept of judicial review. Wilson spoke about the general availability of judicial review at the Pennsylvania ratifying convention. 2 THE Documentary History of the Ratification of the Constitution 450-51 (Merrill Jensen ed., 1976). Wilson's comments about judicial review are confirmed by William Wayne's notes, see 2 id. at 453 ("The legislature may be restrained by the judicial department."), and in his famous Lectures on Law, James Wilson, Comparison of the Constitution of the United States, with That of Great Britain, Lectures on Law XI (1790-1791), in 1 THE Works of JAMES WiLson 309, 330 (Robert G. McCloskey ed., 1967). Madison likewise spoke of a general power of judicial review elsewhere in the Convention, 2 The Records of the Federal Convention, supra note 100, at 27-28, and during ratification, see 3 Debates on the Adoption of the Federal ConstituTION 532 (Jonathan Elliot ed., 1987). Gerry unequivocally spoke in favor of a broader judicial review in the first Congress. 1 The Debates and Proceedings in the Congress of the United STATEs 861 (Joseph Gales \& William W. Seaton eds., 1834).

Even if Kramer were correct, however, he would be conceding the existence of judicial review. If judges were limited to refusing to enforce only those laws that invaded the judiciary's constitutional prerogatives, it would still mean that the Constitution was ordinary law that could be enforced in court.

1282 The Records of the Federal Convention, supra note 100, at 28.

129 Id. at $27-28$.

130 Id. at 376. 
obscure, unknown, and unincorporated, many delegates assumed the existence of judicial review while making arguments about what to include and exclude from the Constitution. Many others likewise assumed that judicial review would exist under the new Constitution without pausing to explain the supposedly obscure and unknown institution.

We do not wish to make too much of the records of the Philadelphia Convention. Professor Kramer is right that the delegates merely proposed a constitution; they did not make it supreme law. Yet, there is quite a bit that Professor Kramer cannot explain about the Convention's proceedings. For Kramer to be right, more than a dozen delegates had to be wrong in concluding that the federal courts would be empowered to judge the constitutionality of federal statutes.

\section{Judicial Review in the Ratification Campaign}

The Constitution's ratification purported to make it part of the Supreme Law of the Land. Hence, it is necessary to examine what those who helped ratify it said about judicial review. Professor Kramer dismisses the ratification evidence in favor of judicial review as a "smattering," "paltry" collection. ${ }^{131}$ Of those who discussed the subject, "few ... imagined [judicial review] as a powerful or important device, and none seemed anxious to emphasize it."132 Judicial review was too obscure-for the "vast majority," judicial review "simply never crossed their minds."133 Finally, judicial review was too controversial to be incorporated into the Constitution as evidenced by the fact that some supposedly cited it as one of the "Constitution's liabilities." 134 At the same time, Professor Kramer assures us that there was plenty of evidence that popular/political defenses of the Constitution were well understood and accepted. People expected that "traditional" defense mechanisms, such as voting and mobbing, were sufficient to safeguard the Constitution. ${ }^{135}$

We have already highlighted our concerns with Professor Kramer's "quantitative" methodology. If one is to adopt a purely quantitative approach, however, one must thoroughly canvass and tally the evidence. Pro-

131 Kramer, We the Court, supra note 1, at 61 (stating that there was "no comprehensive discussion of judicial review at any point in the proceedings" at the Federal Convention); $i d$ at 71-72 (stating that the references to judicial review during the state conventions were "paltry," consisting of only a "smattering of references to judicial review").

132 Id. at 67.

133 Id.

$134 I d$.

135 Id. at 72-73. Professor Kramer charges that we have grievously mangled his argument and conclusions. Kramer, When Lawyers Do History, supra note 1, at 387 . Obviously, we have no intention or desire to misrepresent his arguments; what would be the point? The best we can do, as we have done here, is to quote Professor Kramer's arguments from his articles, as Professor Kramer has written them. Indeed, we do not see any difference between the description of Kramer's claims that we have provided here-that the Framers did not understand the Constitution to create judicial review, that the Constitution itself was not judicially-enforceable law, and that the Founders expected that popular and political forms of enforcement were the exclusive constitutional safeguards-and the arguments that he advances in his comment in this symposium. 
fessor Kramer claims that there were about fifteen speakers who favored judicial review. ${ }^{136}$ In fact, there was more than twice that amount. ${ }^{137}$ When one tallies the number of times individual speakers or writers spoke about judicial review, the number climbs higher still. Dismissing this evidence as "paltry" or a "smattering" is certainly colorful, but does not strike us as accurate.

Another reason Professor Kramer's conclusions are unwarranted is that he cites no one as ever having denied that the Constitution authorized judicial review of federal statutes. Despite the dozens of learned and renowned lawyers who read the Constitution as authorizing judicial review, there apparently was not one delegate or writer who stood up and rejected the notion that the Constitution authorized judicial review. If we are to judge claims solely on the basis of the volume of evidence, his claims fare much more poorly.

Professor Kramer's second claim about the unimportance and impotence of judicial review suffers problems as well. Specifically, the Founders often cited judicial review as the ordinary, ready mechanism by which the Constitution would be vindicated vis-à-vis the Congress and the state legislatures. Given the Federalists' reliance on judicial review, Patrick Henry was right to complain that the people were repeatedly promised that the judiciary would "correct all" congressional overreaching. ${ }^{138}$

Likewise, Professor Kramer's claims that judicial review was too obscure and controversial do not withstand scrutiny. To use his language, in the "flood of pamphlets and essays and editorials that poured from the presses" 139 there is no evidence that anyone claimed: (1) that he did not understand or was unfamiliar with judicial review; (2) that judicial review of federal legislation ought to be opposed on the grounds that it usurped the people's role in defending the Constitution; or (3) that the Constitution did not authorize such judicial review. This silence, in the face of dozens who spoke on behalf of judicial review of federal legislation, is quite revealing. Because judicial review was well known and accepted, there was no need to belabor the point. After all, the more something becomes accepted, the more it is viewed as ordinary and familiar and, therefore, not meriting elaborate explanation. It was enough to mention or allude to judicial review because people recognized how it would constrain Congress. By contrast, a truly revolutionary, unknown institution would have required extensive explanation and defense. ${ }^{140}$

136 Kramer, We the Court, supra note 1, at 71.

137 Prakash \& Yoo, The Origins of Judicial Review, supra note 3, at 953.

138 Henry had mocked those who claimed that the "judiciary ... will correct all" possible congressional infractions of the Constitution because he claimed that the federal judges were dependent upon Congress. 9 The Documentary History of the Ratification of the Con. srirution 962 (John P. Kaminski \& Gaspare J. Saladino eds., 1990).

139 Kramer, We the Court, supra note 1, at 70-71.

140 The muted reaction to judicial review of state law is also instructive. According to Professor Kramer, this type of judicial review was unmistakably authorized by the Constitution's text. Yet, no one expressed confusion about judicial review over state legislation. There is no evidence suggesting that judicial review was well-known, well-understood, and acknowledged to 
Professor Kramer's claim that many cited judicial review as a constitutional liability, ${ }^{141}$ actually refutes his thesis and supports ours. If the Constitution did not authorize judicial review of federal legislation (as Professor Kramer steadfastly insists), no opposition to such judicial review would have been expressed, save for the stray "misinterpretation." After all, one cannot effectively oppose the Constitution by criticizing some alleged feature that has no basis in fact. Indeed, if antifederalists opposed judicial review's inclusion in the Constitution and the Constitution's proponents admitted that judicial review was part of the system as well, one is hard pressed to escape the conclusion that those opposed to judicial review probably were right to object. Professor Kramer has inadvertently confirmed our thesis that the Constitution was understood to authorize judicial review of federal legislation.

Finally, Professor Kramer's conclusions about the exclusivity of popular constitutional safeguards are problematic. Tellingly, Professor Kramer often cites the very same individuals who read the Constitution as favoring judicial review as instead favoring an exclusive popular constitutionalism. ${ }^{142}$ In other words, individuals who erroneously (on his account) read the Constitution as authorizing judicial review are cited by Professor Kramer as supporters of an exclusive popular constitutionalism. As should be obvious, if the same person spoke of both judicial and popular means of defending the Constitution, the person could hardly have believed that only popular means could be used to safeguard the Constitution. Professor Kramer never explains why the same statesmen were wrong about one check on Congress (judicial review), but absolutely correct about another (popular constitutionalism).

We have no quarrel with the notion that the people were the ultimate check on unconstitutional governmental action. Instead, our disagreement stems from Professor Kramer's attempt to transform the final safeguard into the only safeguard. Professor Kramer refuses to acknowledge that the discussions of popular constitutionalism as a constitutional safeguard do not compel the conclusion that all other forms of constitutional enforcement were excluded. Under his approach, for example, Kramer would be forced to conclude that presidents cannot veto bills solely because they are unconstitutional, because this mechanism was not allegedly discussed as often as popular means for constitutional enforcement. Once again, despite the dozens of affirmations that the Constitution authorized judicial review, apparently no one ever rejected this reading of the Constitution.

be a powerful check on state legislation, but was unknown, misunderstood, and denied with respect to federal statutes.

It also bears noting that, apparently, no one ever claimed that the Constitution enshrined asymmetric judicial review. This, despite the fact that Federalists used judicial review to respond to fears that Congress would know no bounds and the antifederalists cleverly used judicial review to claim that Congress could not provide a legislative fix to the Constitution's supposed problems.

141 Id. at 67.

142 Id. at 72 n.277. 


\section{Judicial Review in the Early Years}

Professor Kramer's conclusions undergo a remarkable transformation when he discusses the early years under the Constitution. He candidly admits that the Constitution was "acknowledged" to authorize judicial review throughout the debates of the early Congresses, ${ }^{143}$ and that the institution was "accepted or assumed" to exist as early as the famous 1789 congressional debate about the president's removal authority. ${ }^{144} \mathrm{He}$ also notes that many on the federal bench clearly understood that they could review the constitutionality of federal statutes. ${ }^{145}$

Standing alone, these claims are hardly noteworthy. Others have made them before. But coming from Professor Kramer, these concessions catch the eye. Indeed, they lead the reader to conclude that Professor Kramer must somehow identify the early years of the Republic as the "turning point," both in the acceptance of judicial review and of its perceived incorporation into the Constitution. After all, in the years prior to the drafting of the Constitution, those opposed to judicial review were "ascendant."146 Moreover, during the ratification fight, there is "paltry" evidence that the Constitution was read to authorize judicial review of federal statutes, let alone that judicial review was even generally understood much less accepted. ${ }^{147}$ Hence, although Professor Kramer never expressly identifies the first year of the new Republic as the decisive moment for judicial review, his claims do not make sense unless he hypothesizes some seismic shift in opinion.

As lawyers, we must resist the temptation to pinpoint exactly when a certain concept "originated," such as the separation of powers or federalism-especially when it was the subject of the rapid developments in political and constitutional thought that characterized the Founding period. ${ }^{148}$ Unfortunately, Professor Kramer succumbs to the temptation by weaving a sharp discontinuity into his story.

To begin with, the story is highly improbable. There is something odd about freely admitting that judicial review of federal statutes was "accepted and assumed" in June of 1789 but steadfastly denying it that status in 1.787 or 1788. Recall that Professor Kramer claims that most individuals during the Philadelphia Convention and the ratification process thought of judicial review of federal statutes as an obscure, amorphous, unimportant, and (most importantly) unincorporated practice. Nevertheless, he admits that within one year, essentially the same group of leaders, who were now members of the Washington administration, the first Congress, and the new federal judiciary, sharply reversed course and embraced judicial review. It seems rather

143 Id. at 78 .

$144 I d$.

145 Id. at 76-77.

$146 \mathrm{Id}$. at 55.

147 Id. at 71.

148 Although we have argued that judicial review was generally accepted by $1787-1788$ as a beneficial byproduct of a written Constitution with a separation of powers, we have refrained from pinpointing exactly when, prior to that period, Americans generally supported judicial review. 
unlikely that the nation's elite abruptly reversed their opinions about judicial review in the course of a few months with little or no comment.

Even more problematic, Professor Kramer never attempts to explain this about-face. What caused the dramatic and swift shift in views about judicial review that Professor Kramer advances? Surely there must have been some significant event or crisis that caused people's views to change, both on the desirability of judicial review and on whether the Constitution authorized its application to federal statutes. Professor Kramer never identifies any such event that would have caused the tide to turn.

We know of no evidence that the members of the new federal government regarded their views about judicial review as a contradiction or change in the positions they (and others) held earlier. Indeed, we are aware of no one in the early years of the Republic who claimed (or even hinted) that the Constitution did not authorize judicial review. If the Constitution's text nowhere authorizes judicial review of federal statutes (as Professor Kramer insists), why did no one debunk the claims of those who discussed judicial review in the early years of the Republic? After all, if Professor Kramer's reading of the text is correct, it should have been crystal clear that people were discussing an unauthorized institution. One can only embrace Professor Kramer's reading of the text if one also concludes that people in 1789 thought the "power [of judicial review] was necessarily implicit and so nothing needed to be said" in the Constitution. ${ }^{149}$ Otherwise, one cannot make sense of their discussions and debates. But, if that was true in 1789 , why would not it have been equally true in 1787 and 1788?

Professor Kramer's timeline of sharp discontinuities rings false. In the absence of a sound explanation and a historical grounding, we should be wary of interpretations that posit such dramatic changes in basic understandings about governmental structure. ${ }^{150}$

Given the widespread support for judicial review we believe that what George Nicholas stated at the Virginia Convention about judicial review of federal statutes reflects the general view about all forms of judicial review, both before and after ratification: "[W]ho is to determine the extent of such [legislative] powers? I say the same power which in all well regulated communities determines the extent of Legislative powers-if they exceed these powers, the Judiciary will declare it void."151

149 Recall that this is precisely the claim Professor Kramer rejects in the context of the Philadelphia Convention. Kramer, We the Court, supra note 1 at 67 . Yet, he must accept it here, because otherwise he cannot explain why so many read the Constitution as authorizing judicial review starting in 1789 .

150 One of us has similarly criticized the use of history by Professors Bruce Ackerman and David Golove in claiming that a constitutional moment occurred in 1945 with respect to congressional-executive agreements. See John C. Yoo, Laws as Treaties?: The Constitutionality of the Congressional-Executive Agreement, 99 МicH. L. Rev. 757, 781-85 (2001). Like Professor Kramer, Professors Ackerman and Golove argued that huge majorities of the electorate and the government decided to essentially remove the Treaty Clause from the Constitution, but could not show any sustained discussion or understanding when the alleged change took place. Professor Kramer's account of judicial review suffers from the same problems.

15110 The Documentary History of the Ratification of The Constitution 1327, 1361-62 (John P. Kaminski \& Gaspare J. Saladino eds., 1993) (emphasis added). 


\section{Conclusion}

We have highlighted the problems associated with the view that the Constitution does not authorize judicial review. We believe that Professor Kramer, the most recent prominent critic, has failed to address the constitutional text and structure, has proposed a theory of exclusive constitutional enforcement through political means that is contradicted by the text, practice, and history, and has approached the historical materials from the wrong perspective. Like Professors Wechsler and Choper before him, Professor Kramer has functional doubts about the role of the courts in enforcing the limits of federal power. We believe that his real problem, however, is not with judicial review as an institution. Instead he seems to dislike the substantive results reached by the Rehnquist Court; particularly in the federalism area. Moreover, he opposes judicial supremacy-the idea that the courts decide the Constitution's meaning for all three branches. In denying judicial review in order to undermine both judicial supremacy and the recent federalism cases, however, Professor Kramer tosses out the baby with the bathwater.

We end our essay with several questions designed to prod Professor Kramer to respond to some of the difficulties with his claims. First, if the Constitution were meant to be a political-legal document incapable of judicial enforcement, how can Professor Kramer simultaneously believe that the Founders contemplated that the courts would enforce the Constitution against the states? Second, why does Professor Kramer suppose that so many Founders, members of early Congresses, and Justices of the Supreme Court read the Constitution's text and structure as establishing judicial review of federal statutes when Professor Kramer insists that the Constitution does no such thing? Third, in concluding that judicial review was not accepted in 1787 and 1788 but was accepted by 1789 , what standards does Professor Kramer apply? Finally, what accounts for the dramatic transformation in elite opinion between 1788 and 1789? Professor Kramer insists that, during the ratification campaign, judicial review was neither generally accepted nor regarded as a constitutional feature. Yet Kramer admits that in 1789, judicial review was both generally accepted and regarded as a constitutional feature. While we are likely to remain dubious, Professor Kramer's answers to these questions may help counter some troubling aspects of his claims. It would be unfortunate if he were to respond by ignoring these questions, because we believe that they are shared by many scholars that have found Professor Kramer's historical account to be provocative and colorful, but ultimately unconvincing. 